SAND91-0894 $\cdot$ UC -814

Unlimited Release

Printed July 1992

Yucca Mountain Site Characterization Project

\title{
Anisotropy of the Topopah Spring Member Tuff
}

R. J. Martin III, R. H. Price, P. J. Boyd, R. W. Haupt

Preparad by

Sandia National Laboratories

Albuquerque, New Mexico 87185 and L vermore, California 94550

for the United States Department of Energy

under Contrast DE.AC04.76DPOO789 
"Prepared by Yucca Mountain Site Characterization Project (YMSCP) participants as part of the Civilian Radioactive Waste Management Program (CRWM). The YMSCP is managed by the Yucca Mountain Project Office of the U.S. Department of Energy, DOE Field Office, Nevada (DOE/NV). YMSCP work is sponsored by the Office of Geologic Repositories (OCR) of the DOE Office of Civilian Radioactive Waste Management (OCRWM)."

Issued by Sandia National Laboratories, operated for the United States Department of Energy by Sandia Corporation.

NOTICE: This report was prepared as an account of work sponsored by an

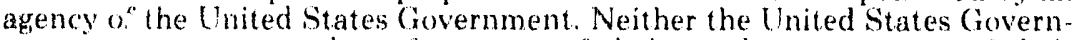
ment nor any agency thereof, nor any of their employees, nor any of their contractors, subcontractors, or their employees, makes any warranty, express or implied. or assumes any legal liability or responsibility for the accuracy, completeness, or usefulness of any information, apparatus, product or process disclosed, or represents that its use would not infringe privately owned rights. Reference herein to any specific commercial uroduct, process, or service by trade name, trademark, manufacturer, or otherwise, does not necessarily constitute or imply its endorsement, recommendation, or favoring by the finited States Covernment, any agency thereof or any of their contractors or subcontractors. The views and opinions expressed herein do not necessarily state or reflect those of the United States Government, any agency thereof or any of their contractors.

Printed in the United States of America. This report has been reproduced directly from the hest available copy.

Available to DOE and DOE contractors from

Office of Sicientific and Technical Information

POBON62

Oak Ridge, TN 37831

Prices available from (615) 576-8.401, FTs 626-8.401

Available to the public from

National Technical Information Service

US Department of Commerce

5285 Port Rowal Rd

Springfield. VA 22161

N'TIS price codes

Printed copy: A(0:

Microfiche copy: A01 
SAND--91-0894

DE92 017356

\title{
SAND91-0894
}

Unlimited Release

Printed July 1992

\section{ANISOTROPY OF THE TOPOPAH SPRING MEMBER TUFF}

\author{
R. J. Martin III ${ }^{\dagger}$, R. H. Price ${ }^{\ddagger}$, P. J. Boyd ${ }^{\dagger}$, and R. W. Haupt ${ }^{\dagger}$

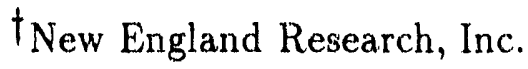 \\ White River Junction, VT 05001 \\ $¥$ Geoscience Assessment and Validation Division \\ Sandia National Laboratories \\ Albuquerque, New Mexico 87185
}

\begin{abstract}
The mechanical properties of the tuffaceous rocks within Yucca Mountain are needed for nearand far-field modeling of the potential nuclear waste repository. If the mechanical properties are significantly anisotropic (i.e, direction-dependent), a more cumplex model is required. Relevant data from tuffs tested in earlier studies indicate that elastic and strength properties are anisotropic. This scoping study confirms the elastic anisotropy and concludes some tuffs are transversely isotropic. An approach for samping and testing the rock to determine the magnitude of the anisotropy is proposed.


This work was performed under the auspices of the U. S. Department of Energy (US DOE), Office of Civilian Radioactive Waste Management, Yucca Mountain Site Characterization Project, under Contract \#DE-AC04-76DP00789. The activities described in this document were performed under Work Breakdown Structure (WBS) Element 1.2.3.2.7.1.3. 


\section{TABLE OF CON'TENTS}

Section

Page

1.0 Introduction

2.0 Experiment Procedures

3.0 Experiment Results 8

4.0 Discussion and Conclusions 15

5.0 References 20

6.0 Figures 21

Table

Page

Table 1. Sample Characteristics

Table 2. Velocity Data for 10/AE/78B

Table 3. Velocity Data for 10/AE/78A 10

Table 4. Velocity Data for 10/AE/78C 11

Table 5. Elastic Coefficients for Sample 10/AE/78A 13

Table 6. Elastic Coefficients for Sample 10/AE/78B 13

Table 7. Engincering Elastic Coefficients 14 


\section{CONTENTS (concluded)}

Figure

Figure 1. Schematic diagram of the sub core orientations and designations for the three specimens obtained from Topopah Spring Member welded tuff specimen $10 / \mathrm{AE} / 78$. The reference coordinate system used in the discussion is shown in the upper left corner.

Figure 2. Compressional ( $\mathrm{P}$-wave) and shear wave ( $\mathrm{S} 1$ and $\mathrm{S} 2$ ) velocities are plotted as a function of confining pressure for a vacuum dry specimen of Topopah Spring Member tuff. The propagation direction is parallel to the axis of symmetry (i.e. normal to the bedding plane).

Figure 3. Compressional ( $\mathrm{P}$-wave) and shear wave ( $\mathrm{S} 1$ and $\mathrm{S} 2$ ) velocities are plotted as a function of confining pressure for a vacuum dry specimen of Topopah Spring Member tuff. The propagation direction is parallel to the bedding plane. $S 1$ has a particle motion in the bedding plane; $\$ 2$ has a particle motion normal to the bedding plane.

Figure 4. Strains parallel to the 1-, 2-, and 3-directions of Topopah Spring Member tuff specimen $10 / \mathrm{AE} / 78$ are plotted as a function of confining pressure. The relation between layering and the coordinate system is shown in Figure 1.

Figure 5. Axial stress is plotted as a function of axial strain for a compression experiment at a confining pressure of $20 \mathrm{MPa}$. The compression direction was normal to the layering.

Figure 6. Axial stress is plotted as a function of axial strain for a uniaxial strain experiment. The compression direction was normal to the layering.

Figure 7. Confining pressure is plotted as a function of axial strain for a uniaxial strain experiment. 


\section{ANISOTROPY OF THE TOPOPAH SPRING MEMBER TUFF}

\subsection{Introduction}

Investigations are under way to determine the mechanical, thermal, and petrological properties of rocks in the vicinity of the potential nuclear waste repository at Yucca Mountain, Nevada. While many routine measurements will be carried out, any comprehensive interpretation of these studies requires an analysis of the variation in properties as a function of orientation with respect to the depositional surface. It is important to determine if the rocks exhibit anisotropic properties. If the elastic and thermal constants vary with orientation (i.e., anisotropy), the fracture strength may also vary with direction.

Anisotropy is due to the preferred alignment of microcracks, elliptical pores, or mineral grains. Microcracks develop along grain boundaries as rocks with anisotropic minerals cool and/or depressurize. This occurs either through uplift or cooling in the case of extrusive rocks. Elliptical pores form most frequently due to the compaction of gas-filled cavities as extrusive rocks such as tuff solidify. Many rocks, especially metamorphic gneisses, schists, and slates, have a preferred orientation of minerals because of the way they form. Because many minerals have a tendency to be anisotropic, then so do the rocks which contain them.

Mechanical anisotropy is directly observed by considering the relations between stress and strain as a function of orientation within the rock. In the most general case, the relationship between a specified state of stress, $\sigma_{k l}$, and the obsirved strains, $\varepsilon_{i, j}$, for a linear elastic solid is given by

$$
\varepsilon_{i j}=S_{i j k l} \sigma_{k l}
$$

where $S_{i j k l}$ is the compliance tensor. (A review of tensor notation and the definitions for anisotropic material properties are given in Nye, 1964.) The number of coefficients required to completely describe the deformation of a solid depends on its property symmetry. It is convenient to describe the symmetry of the elements in terms of crystallography. Accordingly, an isotropic material can be defined by the fewest elastic constants, two, and a triclinic by the most, twenty-one. For an isotropic rock or crystal, the two coefficients are the familiar Young's modulus, E, and Poisson's ratic, ; other elastic moduli (e.g., shear modulus, G) can be calculated from these.

Consider a uniaxial compression experiment on an isotropic rock with the stress applied in the 
1-direction of an orthogonal coordinate system. The following equations then hold.

$$
\begin{gathered}
\varepsilon_{11}=S_{1111} \sigma_{11}=E^{-1} \sigma_{11} \\
\varepsilon_{22}=S_{2211} \sigma_{11}=-\nu E^{-1} \sigma_{11} \\
2\left(S_{1111}-S_{2211}\right)=G^{-1}
\end{gathered}
$$

$S_{1111}$ is the slope of the $\varepsilon_{11}$ vs $\sigma_{11}$ curve (with the strain measured parallel to the stress); $S_{2211}$ is the slope of the $\varepsilon_{22}$ vs $\sigma_{11}$ curve (with the strain measured normal to the stress).

The symmetry of many rocks is sufficiently described with two elastic constants; however, in the case of sedimentary rocks with pronounced bedding, metamorphic sequences, and igneous rocks with pronounced layering or fabric, the elastic coefficients will vary with orientation. Such rocks can be analyzed in terms of a hexagonal symmetry. The axis normal to the layering or fabric is the axis of symmetry, the 3 -axis; the 1 - and 2 -directions are in the plane of the bedding. Properties in the bedding plane are independent of orientation. The elastic deformation of a hexagonal elastic solid can be completely described with five independent coefficients, $S_{1111}, S_{3333}$, $S_{1122}, S_{1133}$, and $S_{1313} . S_{1212}$ is equal to $2\left(S_{1111}-S_{1122}\right) . S_{1111}$ and $S_{3333}$ are the reciprocal of the Young's moduli in the 1- and 3-directions respectively. Rocks characterized in this way are often termed tranversely isotropic (Lo et al., 1986).

Several experiments can be performed to obtain the five compliances. Uniaxial compression experiments on oriented specimens with loading directions parallel to the 1-and 3-directions will give $S_{1111}, S_{3333}, S_{1122}$, and $S_{1133} ; S_{1313}$ can be determined in a shear or torsional test on an appropriately oriented specimen. In some instances due to limited sample availability, a simple: hydrostatic compression experiment can be extremely useful in providing an additional constraint on the measurements or in minimizing the number of specimens required to completely characterize the rock. If the linear compressibilities are measured in the 1 - and 3 -directions $\left(\beta_{1}\right.$ and $\left.\beta_{3}\right)$, the following relationships can be used for determining the elastic coefficients.

$$
\begin{gathered}
\beta_{1}=\left(S_{1111}+S_{1122}+S_{1133}\right) \\
\beta_{3}=\left(S_{3332}+2 S_{1133}\right)
\end{gathered}
$$

Alternatively, it is possible to prescribe the strains, $\varepsilon_{k l}$, acting on an elastic solid and observe the stresses, $\sigma_{i j}$, that develop. For this case the coefficients that relate stress and strain are the stiffnesses, $C_{i j k l}$. The general relationship is given by the following equation.

$$
\sigma_{i j}=C_{i j k l} \varepsilon_{k !}
$$


By analogy with the compliance measurements, in a rock with hexagonal symmetry, five elastic coefficients are also required to determine the state of stress due to a prescribed set of strains. It should be noted that, whereas there is a relationship between the compliances and stiffnesses, it is not a term-for-term reciprocity. The exact relation is given by

$$
C_{i j k l} S_{k l m n}=\delta_{i m} \delta_{j n}
$$

where $\delta_{i m}$ and $\delta_{j n}$ are Kronecker deltas (see Nye, 1964). For example, in the hexagonal system

$$
C_{111}+C_{1122}=\frac{S_{3333}}{S}
$$

where

$$
S=S_{3333}\left(S_{1111}+S_{1122}\right)-2\left(S_{1133}\right)^{2}
$$

The stiffnesses can be measured using several methods. First, each coefficient can be determined in conventional deformation experiments. If a specimen of a rock with hexagonal symmetry is deformed in uniaxial strain parailel to the 3-direction, then two of the stiffnesses can be calculated from the following relationships.

$$
\begin{aligned}
& C_{3333}=\frac{\mathrm{d} \sigma_{33}}{\mathrm{~d} \varepsilon_{33}} \\
& C_{1133}=\frac{\mathrm{d} \sigma_{11}}{\mathrm{~d} \varepsilon_{33}}
\end{aligned}
$$

Thus, it is possible to characterize an anisotropic rock with hexagonal symmetry by determining five terms of elastic stiffnesses or compliances or a combination of both.

In addition to deformation experiments at strain amplitudes on the order of $10^{-6}$ to $10^{-4}$, stiffness coefficients in single crystals are computed from the acoustic velocity in a specified direction. For a rock which can be characterized as transversely isotropic, the following : ions hold (Lo et al., 1986).

$$
\begin{gathered}
C_{1111}=\rho V_{P 1}{ }^{2} \\
C_{1122}=C_{1111}-2 \rho V_{S 1}{ }^{2} \\
C_{3333}=\rho V_{P 3}{ }^{2} \\
C_{1313}^{r}=\rho V_{S 3}{ }^{2} \\
C_{1133}=-C_{1313}+\left\{4 \rho^{2} V_{P 45}{ }^{4}-2 \rho V_{P 45}^{r}{ }^{2}\left(C_{1111}+C_{3333}+2 C_{1313}^{r}\right)+\right. \\
\left.\left(C_{1111}+C_{1313}\right)\left(C_{3333}+C_{1313}\right)\right\}^{0.5}
\end{gathered}
$$


In these equations, $\rho$ is the average bulk density, $V_{P 1}$ is the compressional wave velocity in the 1 direction, $V_{P 3}$ is the compressional wave velocity in the 3-direction, and $V_{P 45}$ is the compressional wave velocity along a ray $45^{\circ}$ to the 1 - and 3 -directions. The shear wave velocities are measured in the 1- and 3-directions, $V_{S 3}$ and $V_{S 1}$. Note that for $V_{S 1}$ both the propagation and vibration directions are in the 1-2 plane.

Previous studies by Olsson and Jones (1980) and Price et al. (1984) have indicated that tuffs from Yucca Mountain exhibit anisotropy in their elastic and strength properties. In light of these findings and the potential importance of anisotropy in evaluating the physical properties of the tuff in the vicinity of the potential repository at Yucca Mountain, a detailed study was initiated on one specimesi of welded tuff from the Topopah Spring Member. Static measurements were performed on oriented cores to determine the compliances and stiffnesses. Ultrasonic measurements were conducted during the deformation tests and the dynamic and static elastic coefficients were compared. The objectives were to (1) see if the tuff could be characterized as isotropic or transversely isotropic and (2) compare the results obtained ultrasonically with those collected during static deformation. This result is important because it is much easier to perform acoustic velocity experiments than deformation tests. Consequently, anisotropy can be measured with a benchtop acoustic system and the results used to estimate the azimuthal variation of the mechanical and thermal properties. 


\subsection{Experiment Procedures}

Small oriented cores were prepared from a larger core obtained from a Busted Butte outcrop. The axis of the large core, $10 / \mathrm{AE} / 78$, was approximately normal to the bedding plane. Three specimens were prepared with the following orientations: parallel to the core axis, normal to the core axis, and at $45^{\circ}$ to the core axis. Figure 1 shows the relative orientation of each specimen with respect to the original core and layering planes within the tuff. A coordinate system is shown on the upper left corner of the diagram; the 3 -axis is normal to the plane of the bedding and the 1 and 2 axes are in the plane of the bedding. This reference coordinate system will be used to describe the symmetry elements of the tuff samples. Sample information is provided in Table 1.

\section{TABLE 1. SAMPLE CHARACTERISTICS}

\begin{tabular}{|c|c|c|c|}
\hline FORMATION: & Paintbrush Tuff & Paintbrush Tuff & Paintbrush Tuff \\
\hline MEMBER: & Topopah Spring & Topopah Spring & Topopah Spring \\
\hline LOCATION: & Busted Butte & Busted Butte & Busted Butte \\
\hline SAMPLE: & $10 / A E / 78 \mathrm{~A}$ & $10 / \mathrm{AE} / 78 \mathrm{~B}$ & $10 / \mathrm{AE} / 78 \mathrm{C}$ \\
\hline ORIENTATION: & $\|$ to Fabric & $\perp$ to Fabric & $15^{\circ}$ to Fabric \\
\hline BULK DENSITY $\left[\mathrm{g} / \mathrm{cm}^{3}\right]$ : & 2.33 & 2.33 & 2.28 \\
\hline POROSITY: & 0.075 & 0.075 & 0.102 \\
\hline
\end{tabular}

Each specimen was ground to a right circular cylinder nominally $2.54 \mathrm{~cm}$ in diameter and in length. Specific attention was given to ensure that the ends of the specimen were flat and parallel to within $\pm 1.3 \times 10^{-3} \mathrm{~cm}$. The specimens were then vacuum dried for 24 hours at $60^{\circ} \mathrm{C}$ and the dry bulk density was determined. Ultraronic velocity measurements were carried out on the dried cores as a function of confining pressure; the experimental procedure is given below. Once the dry measurements were completed, the cores were saturated with water and the grain density of each specimen was determined via the immersion technique. Then the velocity measurements for the saturated condition were conducted as a function of confining pressure. The cores with axes paraliel and normal to the bedding were then tested in hydrostatic compression, confined 
compression and uniaxial strain while simultaneously measuring the compressional and shear wave velocities parallel to their core axes.

\subsection{Ultrasonic Velocity Measurements Under Hydrostatic Pressure}

The ultrasonic velocities of the compressional wave (P) and two shear waves (S) with orthogonal polarizations were measured for each core. The propagation direction was parallel to the core axis. After accurately measuring the length of the core, the core was jacketed with polyolefin, heatshrinkable tubing and positioned between two titanium end pieces containing $1 \mathrm{MHz} \mathrm{P}$ and $\mathrm{S}$ wave piezoelectric crystals. The sample assembly was inserted into a $200 \mathrm{MPa}$ pressure vessel with a $5.5 \mathrm{~cm}$ diameter bore. The confining pressure and pore pressure were manually controlled and the output at each pressure level was measured with Sensotec Model TJE pressure transducers. Hydraulic oil was used as a confining medium, and distilled wat.r was used as a pore fluid. A continuous vacuum was applied to the dry sample during the dry measurements. The velocities were determined at effective pressures of $2.5,5.0,7.5,10,15,20$, and $25 \mathrm{MPa}$. Effective pressure is defined as the difference between confining and pore fluid pressure.

The $\mathrm{P}$ and $\mathrm{S}$ wave velocities of the samples at any pressure were obtained by measuring the one-way travel time of the $\mathrm{P}$ or $\mathrm{S}$ wave along the core axis and dividing it by the sample length. 'The source crystal was excited by an electrical pulse generated with a Panametrics 5055 PR pulser-receiver. 'The signal from the receiver crystal was amplified, high-pass filtered at $0.3 \mathrm{MHz}$, and fed into a LeCroy 9400 digital oscilloscope. The travel time was measured on the oscilloscope screen with a cursor control that has a resolution of 0.02 microseconds. The travel time for both $\mathrm{P}$ and $\mathrm{S}$ waves is picked where the waveform amplitude exceeds a threshold voltage that is $1.25 \%$ of the peak-to-peak amplitude. This technique yields an accurate, self-consistent data set and eliminates much of the uncertainty associated with picking the arrival time. This is a particular advantage for the shear waves when mode conversions generate signals that arrive earlier than the shear wave. The transit time of the $\mathrm{P}$ and $\mathrm{S}$ wave through the end pieces is subtracted from the travel time measured on the oscilloscope. The correction is obtained by measuring the travel time through the transducer assembly without a sample.

\subsection{Hydrostatic Compression on 10/AE/78B}

After the dry and saturated acoustic measurements were completed, sample $10 / \mathrm{AE} / 78 \mathrm{~B}$ was vacuum dried and instrumented with strain gages. Note that the specimen tended to equilibrate to a laboratory dry condition during the instrumentation procedure. Three strain gages, each MicroMeasurements CEA-06-250UW-120, were epoxied to the sample. One gage was positioned on the 
cylindrical surface with its grid aligned parallel to the sample axis. The other gages, mounted on the ends of the cylinder, were oriented at $90^{\circ}$ to each other. Electrical leads were solderct to the gages and the instrumented sample was encapsulated with Devcon Flexane 80. The Flexane 80 had a thickness of approximately $0.75 \mathrm{~cm}$ and served as a jacket to prevent fluid from penetrating the sample. The specimen was inserted into the pressure vessel and pressurized to $50 \mathrm{MFa}$. The output of the strain gage bridges was amplified with a Validyne Model BA 172 DC amplifier and measured with a digital voltmeter. The bridge was checked with a shunt resister before and after the experiment.

\subsection{Hydrostatic, Compression, and Uniaxial Strain Experiments with Velocities}

Hydrostrtic compression, confined compression, and uniaxial strain experiments were performed on specimens $10 / \mathrm{AE} / 78 \mathrm{~A}$ and $10 / \mathrm{AE} / 78 \mathrm{~B}$ while simultaneously measuring the compres. sional and shear wave velocities parallel to the core axis. After vacuum drying the specimens for 24 hours at $60^{\circ} \mathrm{C}$, they were jacketed with $0.13 \mathrm{~mm}$ thick coper. The jackets were then seated to the cores by inserting them in a pressure vessel and pressurizing the system to $20 \mathrm{MPa}$. The specimens were then instrunented with strain gages epoxied parallel (axial) and normal (radial) to the core axis. The strain gages were Micro- Measurements CEA-06-250UW-120. Next the specimen was secured in an ultrasonic transducer assembly similar to that described above. The sample assembly was then inserted into a $200 \mathrm{MPa}$ pressure vessel mounted in a servo-controlled loading frame.

The servo controlled loading frame exerted an axial load on the sample column. The force was measured with an external load cell, NER-020-J-86. For these experiments the press was operated in displacement feedback. "The confining pressure was generated and maintained with a servo-controlled pressure intensifier. The output of a Sensotec Model Z/108-04 pressure transducer provided the feedback signal. For the hydrostatic compression and confined compression experiments, the feedback signal for the pressure system was obtained from the pressure transducer. For the aniaxial strain experiments, the strain gage sensing the strain normal to the loading axis was used as the feedback signal and the confining pressure was allowed to change to maintain a constant transverse (radial) strain.

All the dala were recorded using an IBM/XT-based data acquisition system. The data acquisition program, ACQUIRE, developed at New England Research (NER), was used to collect and store the data. 


\subsection{Experiment Results}

Typical results of the velocity measurenc:is under hydrostatic compression are given in Figures 2 and 3. Figure 2 shows the change in velocity as a inction of pressure for the dry specimen, $10 / \mathrm{AE} / 78 \mathrm{~B}$. The seismic wave propagation direction is normal to the bedding plane. The compressional wave velocity was $4.653 \mathrm{~km} / \mathrm{s}$ at room pressure. As the confining pressure was augmented to $25 \mathrm{MPa}$, the velocity increased only slightly, to $4.662 \mathrm{~km} / \mathrm{s}$. This is a relatively small change for such a large change in pressure. The polarized shear waves exhibit nearly the same velocity (S1 = $2.821 \mathrm{~km} / \mathrm{s} ; \mathrm{S} 2=2.808 \mathrm{~km} / \mathrm{s}$ ) at room pressure and do not increase significantly with increasing pressure. The fact that the polarized shear wave velocities are virtually identical suggests that there is very little anisotropy within the bedding plane. The results for the same specimen under saturated conditions as a function of effective confining pressure are presented in Table 2. Complete saturation was ensured by maintaining a constant pore pressure of $2.5 \mathrm{MPa}$. The saturated compressional wave velocity was slightly greater (approximately $2 \%$ ) than that observed in the dry condition. 'The polarized shear wave velocities were nearly the same for the two orientations and varied $1 \%$ or less from those observed in the dry condition. Both the compressional and shear wave velocities for the saturated condition exhibited the same small pressure dependence that was observed for the dry specimen.

Figure 3 shows the velocity data for the horizontally oriented specimen in a vacuum dry condition. The compressional wave "elocity was approximately $4.953 \mathrm{~km} / \mathrm{s}$ and exhibited virtually no pressure dependence (Table 3 ). This velocity is about $6 \%$ greater than the compressional wave velocity for the vertically oriented specimen (Figure 2). Shear wave velocity anisotropy is evident for waves propagated parallel with the bedding (Figure 3). Shear waves with particle motions perpendicular to the bedding ( $\mathrm{S} 2$ ) had velocities approximately $2.2 \%$ lower than those with motions parallel to the bedding ( $\mathrm{S1}$ ). As with the vertically oriented core, saturation had only a minimal effect on the velocities; the saturated velocities for $10 / \mathrm{AE} / 78 \mathrm{~A}$ are listed in Table 3 as a function of effective confining pressure, although the shear wave anisotropy increased slightly to $2.6 \%$.

Sample $10 / \mathrm{AF}_{7} / 78 \mathrm{C}$ is oriented at $45^{\circ}$ to the bedding plane. The particle motion of $\mathrm{S} 2$ is perpendicular to the trace of the bedding planes, whereas the particle motion of $\mathrm{S} 1$ is parallel to the trace of the bedding planes. Measurements for this orientation are necessary to characterize the anisotropy tensor for the tuff. The results of the vacuum iry and water saturated velocity measurements are presented in Table 4 as a function of effective confining pressure; velocity changes with saturation and increasing pressure are similar to those described for the other orientations. 
TABLE 2. VELOCITY DATA FOR SAMPLE 10/AE/78B

\section{VACUUM DRY}

\begin{tabular}{|c|c|c|c|}
\hline$\left(\mathrm{P}_{c}\right)_{c}[\mathrm{MPa}]$ & P-Wave $[\mathrm{km} / \mathrm{s}]$ & S1-Wave $[\mathrm{km} / \mathrm{s}]$ & S2-Wave $[\mathrm{km} / \mathrm{s}]$ \\
\hline 0.0 & 4.653 & 2.821 & 2.808 \\
\hline 2.5 & 4.662 & 2.821 & 2.808 \\
\hline 5.0 & 4.662 & 2.821 & 2.808 \\
\hline 7.5 & 4.662 & 2.824 & 2.812 \\
\hline 10.0 & 4.662 & 2.827 & 2.815 \\
\hline 15.0 & 4.662 & 2.834 & 2.818 \\
\hline 20.0 & 4.662 & 2.834 & 2.818 \\
\hline 25.0 & 4.662 & 2.834 & 2.821 \\
\hline
\end{tabular}

WATER SATURATED; PORE PRESSURE $=2.5 \mathrm{MPa}$

\begin{tabular}{|c|c|c|c|}
\hline$\left.\left(\mathrm{P}_{c}\right)_{e}[\mathrm{M}] \mathrm{Pa}\right]$ & P-Wave $[\mathrm{km} / \mathrm{s}]$ & S1-Wave $[\mathrm{km} / \mathrm{s}]$ & S2-Wave $[\mathrm{km} / \mathrm{s}$ \\
\hline 0.0 & 4.749 & 2.808 & 2.778 \\
\hline 2.5 & 4.749 & 2.808 & 2.784 \\
\hline 5.0 & 4.749 & 2.808 & 2.787 \\
\hline 7.5 & 4.758 & 2.808 & 2.790 \\
\hline 10.0 & 4.767 & 2.808 & 2.790 \\
\hline 15.0 & 4.767 & 2.808 & 2.787 \\
\hline 20.0 & 4.767 & 2.808 & 2.790 \\
\hline 25.0 & 4.767 & 2.812 & 2.793 \\
\hline
\end{tabular}


TABLE 3. VELOCITY DATA FOR SAMPLF $10 /$ AE/78A

\section{VACUUM DRY}

\begin{tabular}{|c|c|c|c|}
\hline$\left(\mathrm{P}_{c}\right)_{e}[\mathrm{MPa}]$ & P-Wave $[\mathrm{km} / \mathrm{s}]$ & S1-Wave $[\mathrm{km} / \mathrm{s}]$ & S2-Wave $[\mathrm{km} / \mathrm{s}]$ \\
\hline 0.0 & 4.953 & 2.945 & 2.882 \\
\hline 2.5 & 4.953 & 2.952 & 2.885 \\
\hline 5.0 & 4.953 & 2.952 & 2.885 \\
\hline 7.5 & 4.953 & 2.956 & 2.888 \\
\hline 10.0 & 4.953 & 2.956 & 2.888 \\
\hline 15.0 & 4.963 & 2.956 & 2.892 \\
\hline 20.0 & 4.963 & 2.966 & 2.895 \\
\hline 25.0 & 4.973 & 2.966 & 2.895 \\
\hline
\end{tabular}

WATER SATURATED; PORE PRESSURE $=2.5 \mathrm{MPa}$

\begin{tabular}{ccccc}
$\frac{\left(\mathrm{P}_{c}\right)_{e}[\mathrm{MPa}]}{$\cline { 1 - 1 }} & & P-Wave $[\mathrm{km} / \mathrm{s}]$ & S1-Wave $[\mathrm{km} / \mathrm{s}]$ & S2-Wave $[\mathrm{km} / \mathrm{s}]$ \\
0.0 & 4.963 & 2.922 & 2.846 \\
2.5 & 4.963 & 2.925 & 2.849 \\
5.0 & 4.963 & 2.928 & 2.853 \\
7.5 & 4.973 & 2.928 & 2.856 \\
10.0 & 4.973 & 2.928 & 2.856 \\
15.0 & 4.992 & 2.928 & 2.856 \\
20.0 & 4.992 & 2.932 & 2.856 \\
25.0 & 4.992 & 2.932 & 2.859
\end{tabular}


TABLE 4. VELOCITY DATA FOR SAMPLE 10/AE/78C

\section{VACUUM DRY}

\begin{tabular}{|c|c|c|c|}
\hline$\left(\mathrm{P}_{c}\right)_{e}[\mathrm{MPa}]$ & P-Wave $[\mathrm{km} / \mathrm{s}]$ & S1-Wave $[\mathrm{km} / \mathrm{s}]$ & S2-Wave $[\mathrm{km} / \mathrm{s}]$ \\
\hline 0.0 & 4.636 & 2.793 & 2.790 \\
\hline 2.5 & 4.653 & 2.793 & 2.790 \\
\hline 5.0 & 4.653 & 2.796 & 2.790 \\
\hline 7.5 & 4,653 & 2.796 & 2.793 \\
\hline 10.0 & 4.662 & 2.802 & 2.799 \\
\hline 15.0 & 4.662 & 2.802 & 2.802 \\
\hline 20.0 & 4.662 & 2.805 & 2.805 \\
\hline 25.0 & 4.662 & 2.808 & 2.812 \\
\hline
\end{tabular}

WATER SATURATED; PORE PRESSURE $=2.5 \mathrm{MPa}$

\begin{tabular}{|c|c|c|c|}
\hline$\left(\mathrm{P}_{c}\right)_{e}[\mathrm{MPa}]$ & P-Wave $[\mathrm{km} / \mathrm{s}]$ & S1-Wave $[\mathrm{km} / \mathrm{sj}$ & S2-Wave $[\mathrm{km} / \mathrm{s}]$ \\
\hline 0.0 & 4.705 & 2.721 & 2.739 \\
\hline 2.5 & 4.705 & 2.721 & 2.742 \\
\hline 5.0 & 4.723 & 2.721 & 2.745 \\
\hline 7.5 & 4.723 & 2.721 & 2.748 \\
\hline 10.0 & 4.723 & 2.721 & 2.751 \\
\hline 15.0 & 4.723 & 2.721 & 2.751 \\
\hline 20.0 & 4.723 & 2.727 & 2.754 \\
\hline 25.0 & 4.723 & 2.730 & 2.757 \\
\hline
\end{tabular}


In order to compare the elastic coefficients for tuff calculated from the velocity data with those obtained from static measurements, hydrostatic compression, confined compression, and uniaxial strain experiments were performed on dry tuff specimens. Figure 4 shows the results of the hydrostatic compression experiment for specimen $10 / \mathrm{AE} / 78 \mathrm{~B}$; the core axis for this specimen was normal to the apparent bedding. Three strains are plotted as a function of pressure: normal to the layering (the 3-direction) and parallel to the plane of the bedding (the 1- and 2-directions). The greatest strain is observed normal to the bedding. Parallel to the bedding plane, the strains, measured with two orthogonal gages, were smaller than the axial strain; the gages yielded very similar strains at each observation level. The slope of the strain versus pressure curve in a given direction gives the linear compressibility in that direction. The linear compressibilities in the 3and 1-directions were as follows.

$$
\begin{aligned}
& \beta_{3}=1.627 \times 10^{-2} \mathrm{GPa}^{-1} \\
& \beta_{1}=1.356 \times 10^{-5} \mathrm{GPa}^{-1}
\end{aligned}
$$

The difference in the linear compressibilities is $20 \%$. 'This is much greater than the anisotropy' determined acoustically. Furthermore, the changes in all three strains with confining pressure were nearly linear, meaning the compressibilities were independent of pressure. Each pressure versus strain curve exhibits a small curvature below $10 \mathrm{MPa}$. The non-linearity is most noticeable in the 1 - and 2-directions. This nearly independent behavior with pressure is consistent with the velocity measurements, which also showed no change in velocity with confining pressure.

In order to completely determine the compliances for the specimen, several nonhydrostatic experiments were carried out. Confined compression tests were performed on $10 / \mathrm{AE} / 78 \mathrm{~A}$ and $10 / \mathrm{AE} / 78 \mathrm{~B}$ at a fixed confining pressure of $20 \mathrm{MPa}$. The results of the run on $10 / \mathrm{AE} / 78 \mathrm{~B}$ are shown in Figure 5, with stress plotted as a function of strain $\left(\sigma_{33}\right.$ and $\left.\varepsilon_{33}\right)$. The slope of the curve is $S_{3333}{ }^{-1}$. The slope of the transverse strain, $\varepsilon_{11}$, vs longitudinal strain, $\varepsilon_{33}$, is $S_{1133}{ }^{-1}$. The results of these calculations, as well as those for the related experiments on $10 / \mathrm{AE} / 78 \mathrm{~A}$, are presented in Table 6.

Finally, it seemed worthwhile to directly measure the stiffnesses of the specimens by conducting several uniaxial strain experiments. The results of a typical cyclic load for $10 / \mathrm{AE} / 78 \mathrm{~B}$ are shown in Figures 6 and 7. The axial stræss, $\sigma_{33}$, and the radial stress (or confining pressure), $\sigma_{11}$, are plotted as a function of axial strain, $\varepsilon_{33}$, in Figures 6 and 7 , respectively. For these tests $\varepsilon_{11}$ is held constant and equal to zero. The slope of the $\sigma_{33}$ vs $\varepsilon_{33}$ loading curve yields $C_{3333}$; the slope of the $\sigma_{11}$ vs $\varepsilon_{33}$ curve yields $C_{1133}$. The stiffnesses for this data set were computed at a mean istress of $20 \mathrm{MPa}$; the values are presented in Table 6. 
TABLE 5. ELAS'TIC COEFFICIENTS FOR SAMPLE 10/AE/78A

$\begin{array}{lcccc} & S_{1111} & \beta_{1} & C_{1111} & C_{1122} \\ & \underline{\mathrm{GPa}^{-1}} & \underline{\mathrm{GPa}^{-1}} & \underline{\mathrm{GPa}} & \underline{\mathrm{GPa}} \\ \text { Static: } & 0.0185 & 0.0136 & 53.90 & 12.66 \\ \text { Dynamic: } & & & 57.21 & 15.79\end{array}$

TA 9LE 6. ELASTIC COEFFICIENTS FOR SAMPLE 10/AE/78B

$\begin{array}{ccccccc}S_{3333} & S_{1122} & S_{1133} & \beta_{3} & C_{3333} & C_{1133} & C_{1313} \\ \mathrm{GPa}^{-1} & \underline{\mathrm{GPa}^{-1}} & \underline{\mathrm{GPa}^{-1}} & \underline{\mathrm{GPa}^{-1}} & \underline{\mathrm{GPa}} & \underline{\mathrm{GPa}} & \underline{\mathrm{GPa}}\end{array}$

Static: $\quad \begin{array}{llllllll}0.0148 & -0.0057 & -0.0017 & 0.0163 & 53.53 & 15.37 & -\end{array}$

$\begin{array}{llll}\text { Dynamic: } & 50.89 & 9.30 & 19.00\end{array}$

Table 7 presents the static and dynamic elastic constants in terms of the more commonly used engineering constants, Young's nodulus, Poisson's ratio, and bulk modulus. 'Two Young's moduli are calculated; normal to the layering (the 3-direction) and in the plane of the bedding (the 1-direction). Three Poisson's ratios are given (Lo et al., 1986):

$$
\begin{aligned}
& \nu_{1}=\frac{\mathrm{d} \varepsilon_{11}}{\mathrm{~d} \varepsilon_{22}} \\
& \nu_{2}=\frac{\mathrm{d} \varepsilon_{33}}{\mathrm{~d} \varepsilon_{11}} \\
& \nu_{3}=\frac{\mathrm{d} \varepsilon_{33}}{\mathrm{~d} \varepsilon_{11}}
\end{aligned}
$$


TABLE 7. ENGINEERING ELASTIC COEFEICIENTS

\begin{tabular}{lccccccc} 
& \multicolumn{2}{c}{$\begin{array}{c}\text { Young's Modulus [GPa] } \\
\text { 3-direction }\end{array}$} & 1-direction & & & \multicolumn{4}{c}{ Poisson's Ratio } \\
& & & & $\nu_{1}$ & $\nu_{2}$ & $\nu_{3}$ \\
Static: & 46.43 & 48.11 & 23.09 & 0.167 & 0.239 & 0.231 \\
Dynamic: & 44.42 & 50.20 & 28.62 & 0.212 & 0.238 & 0.211
\end{tabular}

Before proceeding, several additional observations must $2:$ mentioned. Hydrostatic compression tests were run on the copper jacketed specimens prior to the defurmational experiments. Four observations are pertinent.

(i) The volume compressibilities for both specimens (10AE78 A and 10AE78B) were nearly identical.

(ii) The velocities measured on the copper jacketed specimens in the deformational apparatus were identical to those collected in the vacuum dry condition using the hydrostatic, velocity measuring system.

(iii) The volume compressibility for the copper jacketed specimen was $3.628 \times 10^{-2} \mathrm{GPa}^{-1}$, whereas the volume compressibility for the specimen jacketed in Flexane was $4.305 \times 10^{-2}$ $\mathrm{GPa}^{-1}$.

(iv) The dynamic stiffnesses calculated from the velocities measured in the uniaxial strain experiments were in excellent agreernent with those computed from the velocities collected under hydrostatic pressure; the differences were less than $0.5 \%$. 


\subsection{Discussion and Conclusions}

The experimental data for the Topopah Spring Member welded tuff samples include ultrasonic compressional and shear wave velocities as a function of sample orientation, saturation, pressure, and differential stress (confined compression and uniaxial strain tests). 'The effects of sample anisotropy are apparent in these measurements. Specifically, the tuff is significantly more compliant normal to the layering than within the bedding plane.

The velocity data indicate that the anisotropy, although small, is consistent with a physically intuitive model in which the welding and compaction process has caused the tuff to become transversely isotropic. The axis of symmetry is perpendicular to the prefferred orientation of the shard matrix, which is tha result of gravity and flow during deposition of the ash flow tuff (Price et al., 1985; 1987). Consequently, this prefferred orientation of the shard matrix and, possibly, the pore distribution produced the anisotropy.

For an ideal transversely isotropic material, four relationships hold.

(i) The axis of symmetry is normal to the bedding plane. This is the slow direction for P waves, that is, the minimum velocity. Furthermore, $S$ waves propagating parallel to the axis of symmetry have the same velocity regardless of their vibration direction (particle motion).

(ii) For propagation directions normal to the axis of symmetry (parallel to the bedding plane), $\mathrm{P}$ wave velocities are a maximum. Shear waves with a particle motion parallel to the bedding plane have a greater velocity than those with a particle motion perpendicular to the bedding.

(iii) For propagation directions between the two principal directions, the velocities for $\mathrm{P}$ waves and $\mathrm{S}$ waves with particle motion parallel to the trace of the beiding are intermediate to those observed along the principal directions.

(iv) The velocity of shear waves with a component of particle motion parallel to the axis of symmetry may be either higher or lower than the velocity perpendicular to the axis of symmetry.

Because the pressure dependence of velocity is relatively small, the degree of anisotropy can be described by referring to the velocities measured at low pressure. 'The $\mathrm{P}$ wave velocities in the two samples oriented in the vertical and horizontal direction differ by approximately $0.300 \mathrm{~km} / \mathrm{s}$ for the dry samples, or about $6.4 \%$. The slow direction for the $\mathrm{P}$ wave is parallel with the axis 
of symmetry, which is parallel with the axis of the vertically oriented sample, $10 / \mathrm{AE} / 78 \mathrm{~B}$. The greatest $\mathrm{S}$ wave anisotropy is perpendicular to the axis of symmetry. In this direction the two $\mathrm{S}$ waves differ by approximately $0.063 \mathrm{~km} / \mathrm{s}$ for the dry sample, or about $2.2 \%$. The $\mathrm{S}$ wave with the particle motion perpendicular to the axis of symmetry (S1) is faster than that with the particle motion parallel with the axis of symmetry (S2).

Although these velocities are consistent with a transversely isotropic model, sample variability in this limited selection of cores is also apparent. Ideally, the $\mathrm{P}$ wave velocities propagated at $45^{\circ}$ are intermediate between those parallel and perpendicular to the axis of symmetry. In the data collected for the core oriented at $45^{\circ}$, however, this direction has the lowest $\mathrm{P}$ wave velocities. The lowest $S$ wave velocities of either polarization were also recorded for this sample. In addition, this sample has the lowest measured bulk density and highest porosity. A reasonable explanation is that the large core from which these smaller oriented samples were prepared was not homogeneous. Therefore, variability should be averaged out with measurements on a larger set of cores of this size or else larger core sizes.

As discussed in Section 1.0, to completely characterize the elastic behavior of a rock or a crystal with hexagonal symmetry, five coefficients must be determined. For the welded tuff in the dry condition at 20.0 MPa, the five compliance coefficients computed from the velocity data are as follows.

$$
\begin{aligned}
& C_{1111}=57.3 \times 10^{5} \mathrm{GPa} \\
& C_{3333}=50.6 \times 10^{5} \mathrm{GPa} \\
& C_{1122}=16.8 \times 10^{5} \mathrm{GPa} \\
& C_{1313}=18.5 \times 10^{5} \mathrm{GPa} \\
& C_{1133}=9.3 \times 10^{5} \mathrm{GPa}
\end{aligned}
$$

These values are based on a limited set of velocity measurements. $C_{1133}$, which is based in part on the suspect $\mathrm{P}$ wave velocity measured in the $45^{\circ}$ direction, needs further measurements.

Typically the velocities measured in rocks increase with confining pressure. For the tuff samples, however, the pressure dependence of velocity is very small. Over the $25 \mathrm{MPa}$ range of pressure, the largest increase in $\mathrm{P}$ wave velocity is $0.03 \mathrm{~km} / \mathrm{s}$ for the water saturated horizontal sample, or about $0.58 \%$. Similarly, for the $S$ wave the largest increase is $0.021 \mathrm{~km} / \mathrm{s}$ for the $S 1$ wave in the dry horizontal sample, or about $0.71 \%$. In addition to, at most, a small pressurc dependence, the increase in velocity with pressure is approximately linear. This indicates that very little of the total porosity is in the form of compliant cracks, which would give rise to large, 
nonlinear increases in velocities as a function of pressure. During the welding and compaction process, all of the cracks and grain contacts were closed and cemented by the flow of the matrix, the vapor phase activity and diffusion through the matrix, and the deposition of tridymite (Price et al., 1985). In addition, the devitrification process did not create new low-aspect-ratio voids (Price et al., 1985; 1987).

The effects of water saturation on velocity in these samples are consistent with the interpretation of a largely noncompliant porosity. Typically, the introduction of water into the pore space increases the overall bulk modulus while having a much smaller effect on the shear modulus. Consequently, $P$ wave velocities increase upon saturation, and a greater increase is obser 1 when porosity is contained in fine, compliant, crack-like pore shapes (Cheng, 1978). The $\mathrm{S}$ wave velocities decrease with increasing water saturation and crack concentration. If all of the porosity is perfectly spherical, the bulk and shear moduli are independent of water saturation (as if the pores were not even there). Thus, the $\mathrm{P}$ wave and $\mathrm{S}$ wave velocities decrease in proportion to the increase in density when going from the dry to saturated condition. For the welded tuff the majority of the porosity is most likely spherical. The saturated S wave velocities are lower than dry, and the decrease is nearly predicted by the increase in water-saturated density. The saturated $P$ wave velocities are equal to or slightly higher than dry, indicating a pore population somewhat less than spherical. Applying the model developed by Cheng (1978), the porosity can be modelled with a distribution of pore shapes with aspect ratios of between 1.0 (spheres) and 0.1 (oblate spheroids).

There is one observation in the dry and saturated data that indicates that the long axis of the oblate spheroidal or tabular pores have a preferred orientation parallel with the lineation or bedding. The effects of saturation are greatest on $\mathrm{P}$ wave velocities in the vertical direction. In going from a dry to a saturated condition, $\mathrm{P}$ wave velocities increase by $0.096 \mathrm{~km} / \mathrm{s}$ or about $2.06 \%$. This is not a large increase, but is consistent with a preferred orientation parallel to bedding. In the horizontal direction the increase is only $0.01 \mathrm{~km} / \mathrm{s}$, or $0.2 \%$, while at $45^{\circ}$ the increase is 0.07 $\mathrm{km} / \mathrm{s}$, or about $1.49 \%$. This is also what would be anticipated with a transversely isotropic model, and indicates that at least some of the anisotropy is due to the preferred orientation of pores.

The anisotropy of the welded tuff is also apparent in the linear compressibility data. The linear compressibility, $\beta_{3}$, is approximately $20 \%$ greater parallel to the symmetry axis than perpendicular to the symmetry axis, $\beta_{1}$. Furthermore, the two linear compressibilities measured in the bedding plane agree very closely. Therefore, the strain measurements are consistent with a transversely isotropic material. The strain dependence on pressure is nearly linear in all directions, indicating 
that the majority of the porosity is not in the form of low-aspect-ratio pores, which would cause a nonlinear behavior at low pressures. In the 3-direction, the strain is larger either because of the preferred orientation of pores parallel with the lineation, or due to the anisotropy and prelerred orientation of the mineralogy.

While the linear compressibility data are consistent with a transversely isotropic rock, the two measurements are not sufficient to fully describe the material. For this reason, additional experiments were performed in confined compression and uniaxial strain. The results of these ineasurements are compiled in Tables 5,6, and 7. Specifically, it is possible to compare the static and dynamic stiffnesses and engineering elastic constants. The coefficients $C_{1111}$ and $C_{1122}$ are in good agreement for the static and dynamic measurements. The dynamic moduli are somewhat greater than the static. The strain amplitude of static measurements is three to five crders of magnitude larger than dynamic measurements. This static-to-dynamic ratio is in good agreement with previous results (Simmons and Brace, 1965; Cheng and Johnston, 1981). The more crack-like porosity in the sample, the greater is the static-to-dynamic ratio. As pressure increases, the crack porosity decreases and the two compressibilities tend to converge. There was no convergence at, higher pressures, and this reinforces the interpretation of oblate rather than crack-like porosity.

A problem arises for $C_{3333}$ and $C_{1333}$. In both instances, the static coefficients exced the dynamic. Given the magnitude of the difference, it is well outside the bounds of normal experimental error and directly contradicts the linear compressibility data presented in Figure 4. The measurements were repeated and all the calibrations checked. The result was unchanged. The crror apparently resides in the test geometry. The samples were $2.54 \mathrm{~cm}$ in both length and diameter. It appears that the impedance contrast between the titanium iransducers and the rock altered the strain field near the interface. This effect has been noted by others (e.g., S. R. Brown, personal communication). Furthermore, due to the short sample length, the size of the strain gage grid, and the position of the gages on this particular specimen, the strains have been underestimated. This leads to an overestimation of the stiffnesses. There is no immediate explanation as to why the data on specimen $10 / \mathrm{AE} / 78 \mathrm{~A}$ yielded consistent results as did $10 / \mathrm{AE} / 78 \mathrm{~B}$ when they were tested in true hydrostatic compression. The results cannot be attributed to a change in the sample due to multiple loading cycles, because the velocities remained unchanged throughout the sample history. The discrepancy is also reflected in the Young's modulus in the 3-direction; the static modulus exceeds the dynamic. The results indicate that a greater length-to-diameter ratio is necessary for these measurements. The commonly accepted ratio of length-to-diameter is 1.0 to 2.2 to avoid significant end effects. 
The results of the study on this specimen of welded tuff clearly indicate that the rock is anisotropic and its elastic behavior can be adequately characterized with five coefficients. The anisotropy of the welded tuff is apparent in the ultrasonic velocity and strain measurements. The source of the anisotropy is either a preferred distribution of ellipsoidal and tabular pores parallel with the lineation or else a preferred distribution of the mineralogy. The degree of anisotropy is on the order of $7 \%$ or less in velocity and $20 \%$ from the linear compressibilities. Because there is apparently a fair degree of sample inhomogeneity additional measurements on a larger set of samples would be necessary for a complete characterization. 


\title{
5.0 References
}

\author{
Cheng, C. H., 1978
}

Seismic Velocities in Porous Rocks: Direct and Inverse Problems, Ph.D. thesis, M.I.T., Carnbridge. (NNA.911007.0004)

Cheng, C. H., and D. H. Johnston, 1981

Dynamic and Static Moduli, Geophys. Res. Letters, 8, 39-42. (NNA.910923.0006)

Lo, T., K. B. Coyner, and M. N. Toksoz, 1986

Experimental Determination of Elastic Anisotropy of Berea Sandstone, Chicopee Shale, and Chelmsford Granite, Geophysics, 51, 164-171. (NNA.910306.0117)

Nye, J. F., 1985

Physical Properties of Crystals, The University Press, Oxford. (NNA.911021.0031)

Olsson, W.A., and A. K.Jones, 1980

Rock Mechanics Properties of Volcanic Tuffs from the Nevada Test Site, SAND80-1453, Sandia National Laboratories, Albuquerque, NM. (NNA.870406.0497)

Price, R.H., J.R. Connolly, and K. Keil, 1987

Petrologic and Mechanical Properties of Outcrop Samples of the Welded, Devitrified Topopah Spring Member of the Paintbrush Tuff, SAND86-1131, Sandia National Laboratories, Albuquerque, NM. (HQS.880517.1704)

Price, R.H., F.B.Nimick, J.R.Connolly, K. Keil, B.M.Schwartz, and S.J.Spence, 1985

Preliminary Characterization of the Petrologic, Bulk, and Mechanical Properties of a Lithophysal Zone Within the Topopah Spring Member of the Paintbrush Tuff, SAND84-0860, Sandia National Laboratories, Albuquerque, NM. (NNA.870406.0156)

Price, R.H., S.J.Spence, and A.K.Jones, 1984

Uniaxial Compression Test Series on Topopah Spring Tuff from USW GU.3, Yucca Mountain, Nevada Test Site, SAND83-1646, Sandia National Laboratories, Albuquerque, NM. (NNA.870406.0252)

Simmons, G., and W.F.Brace, 1965

Comparison of Static and Dynamic Measurements of Compressibility of Rocks, J. Geophys. Res., 70, 5649-5656. (NNA.910923.0007) 


\subsection{Figures}

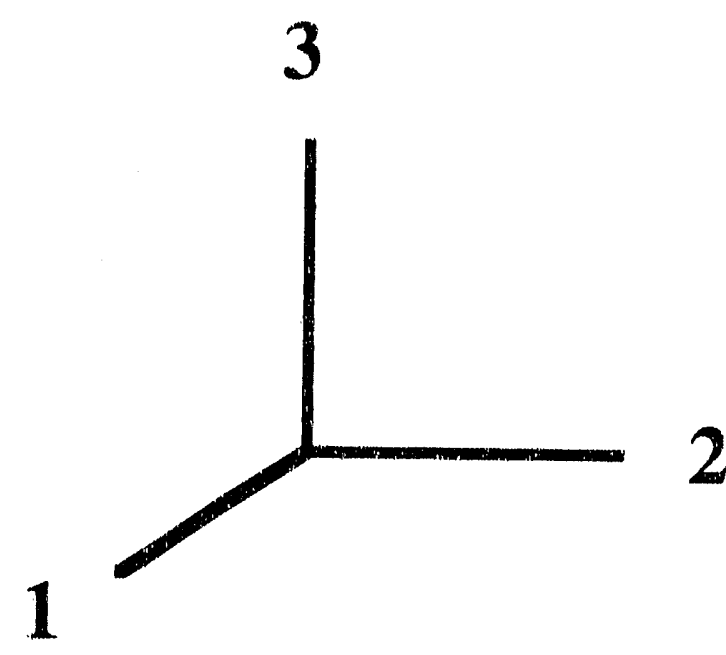

$10 / \mathrm{AE} / 78 \mathrm{C}$
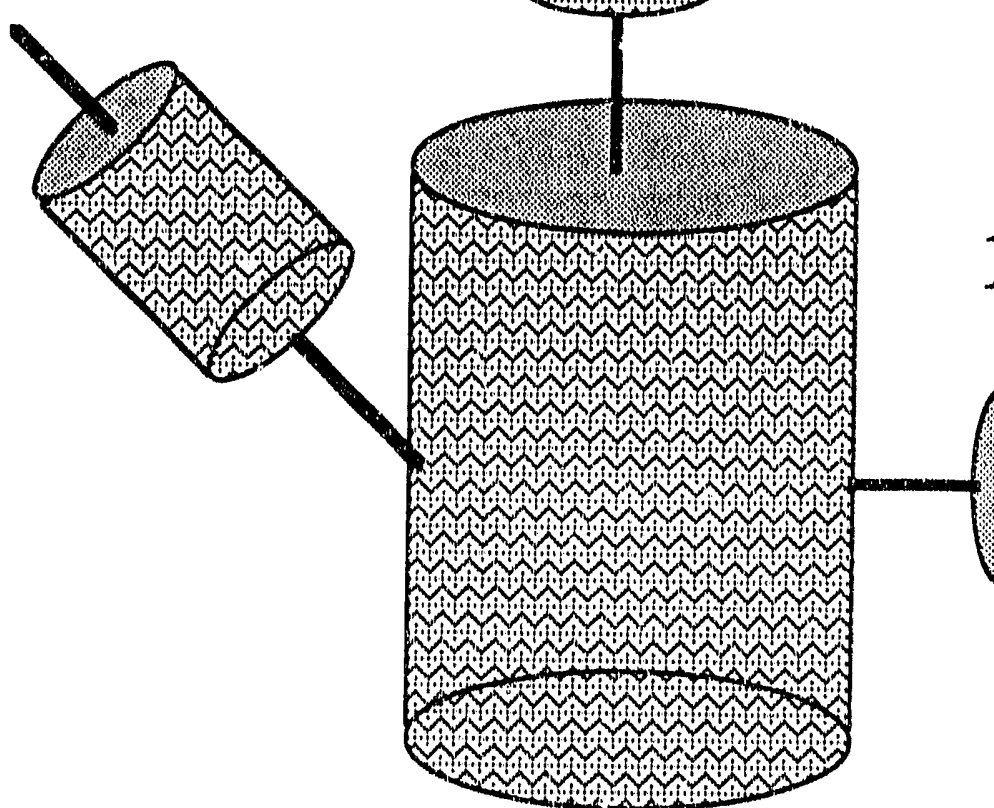

10/AE/78A

Figure 1. Schematic diagram of the sub-core orientations and designations for the three specimens obtained from Topopah Spring Member welded tuff specimen 10/AE/78. The reference coordinate system used in the discussion is shown in the upper left corner. 


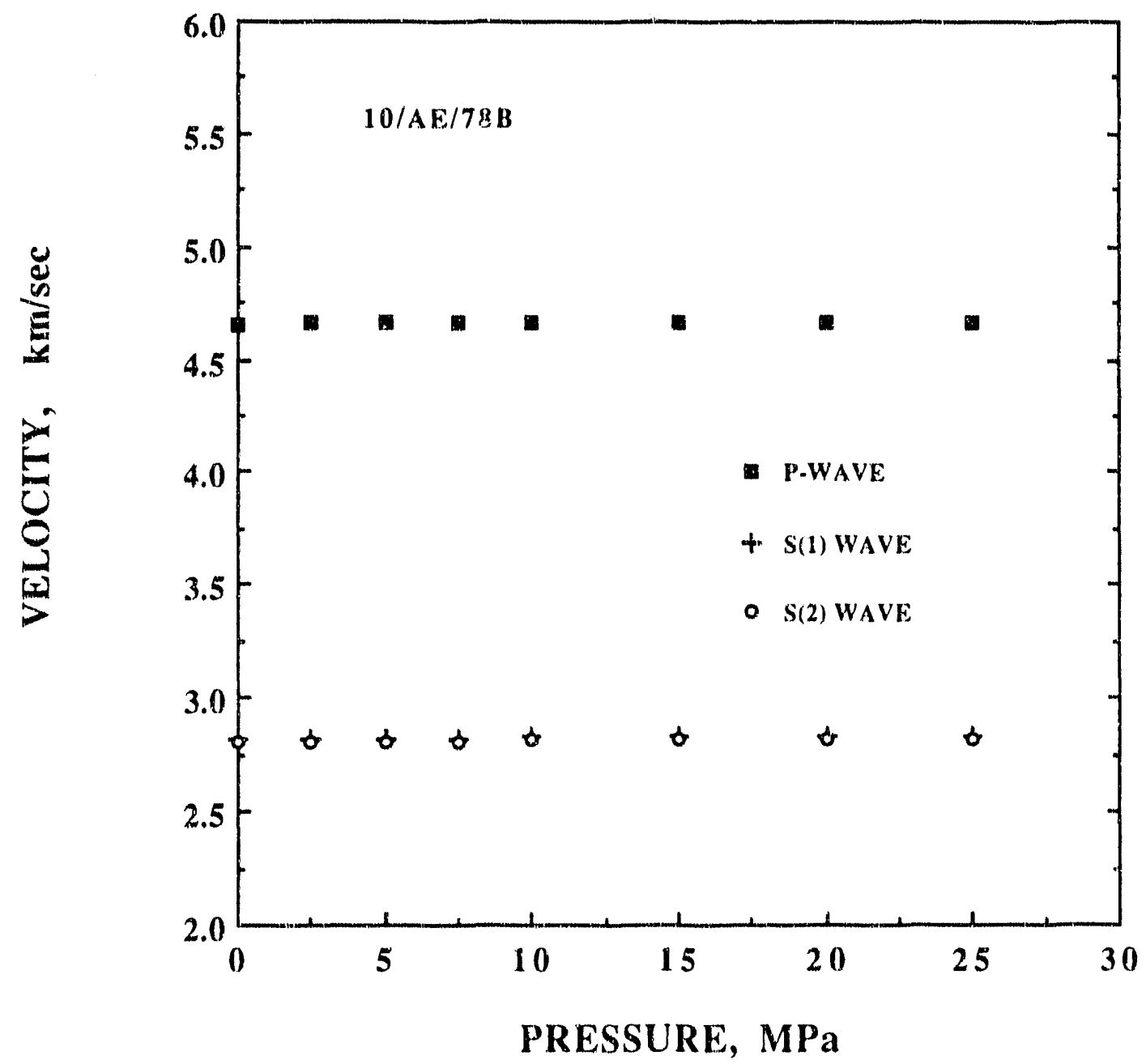

Figure 2. Compressional ( $\mathrm{P}$-wave) and shear wave ( $\mathrm{S} 1$ and $\mathrm{S} 2$ ) velocities are plotted as a function of confining pressure for a vacuum dry specimen of Topopah Spring Member tuff. The propagation direction is parallel to the axis of symmetry (i.e. normal to the bedding plane). 


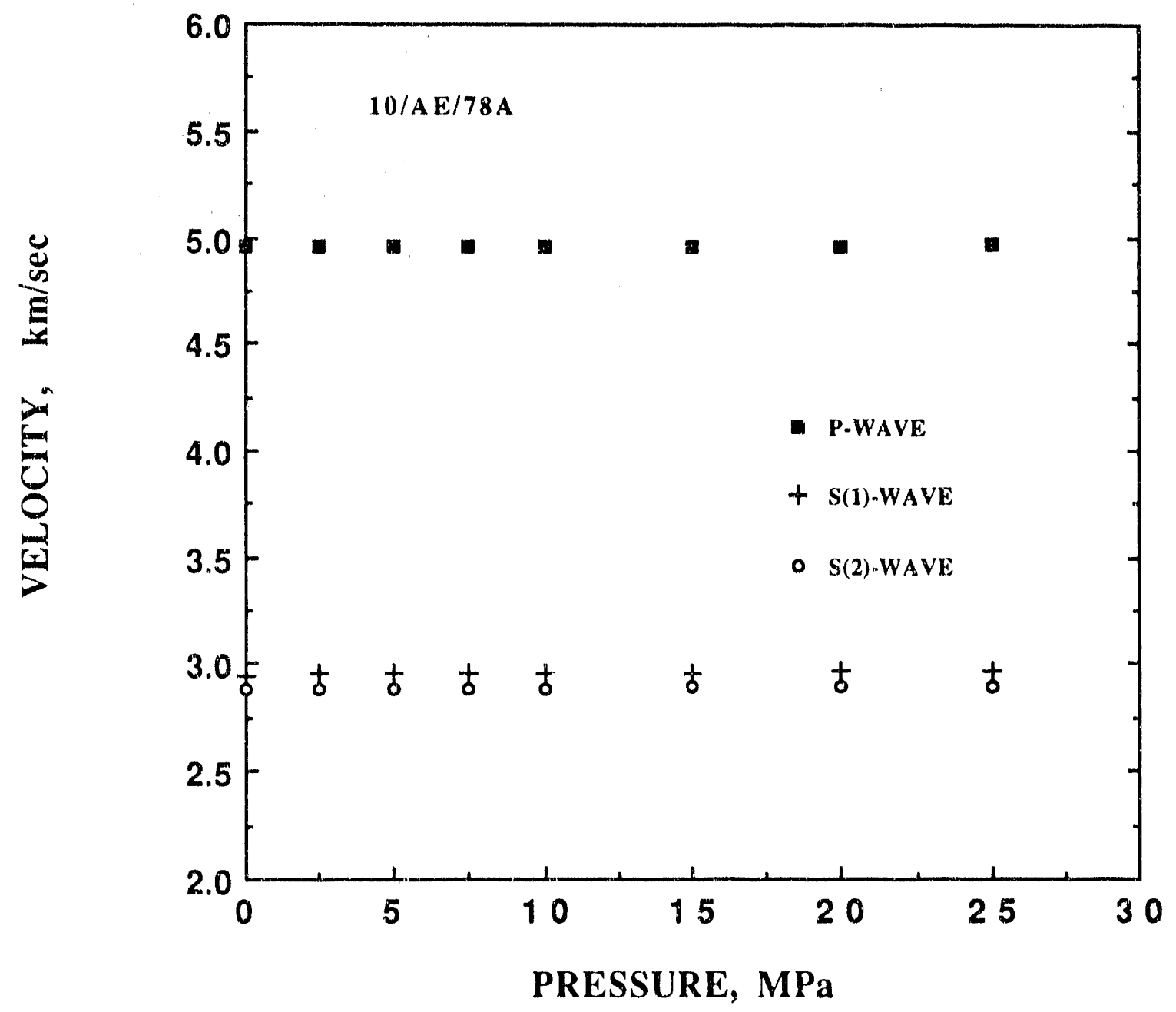

Figure 3. Compressional (P-wave) and shear wave (S1 and S2) velocities are plotted as a function of confining pressure for a vacuum dry specimen of Topopah Spring Member tuff. The propagation direction is parallel to the bedding plane. S1 has a particle motion in the bedding plane; $\$ 2$ has a particle motion normal to the bedding plane. 


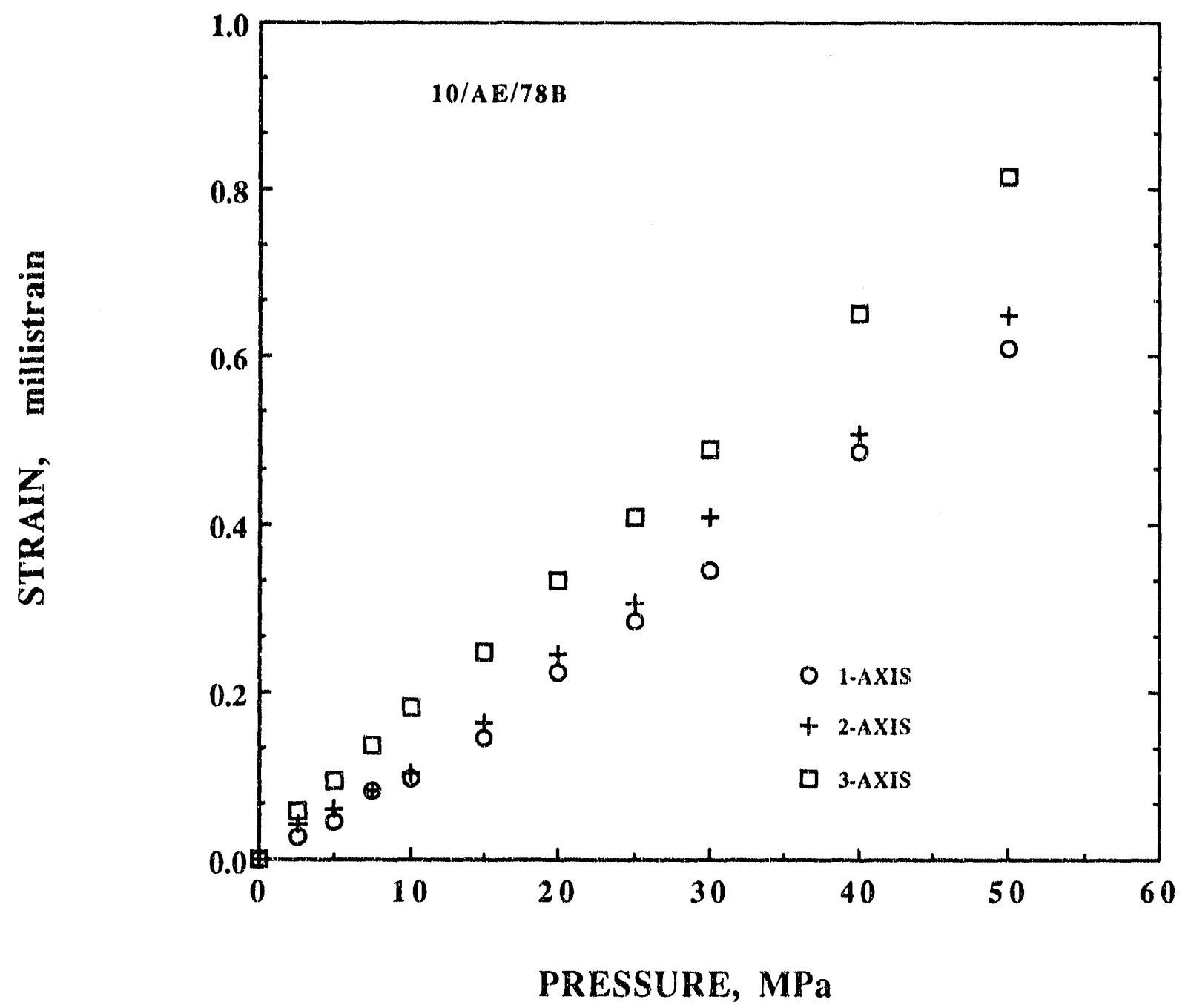

Figure 4. Strains parallel to the 1-, 2-, and 3- directions of Topopah Spring Member tuff specimen $10 / \mathrm{AE} / 78$ are plotted as a function of confining pressure. The relation between layering and the coordinate system is shown in Figure 1. 


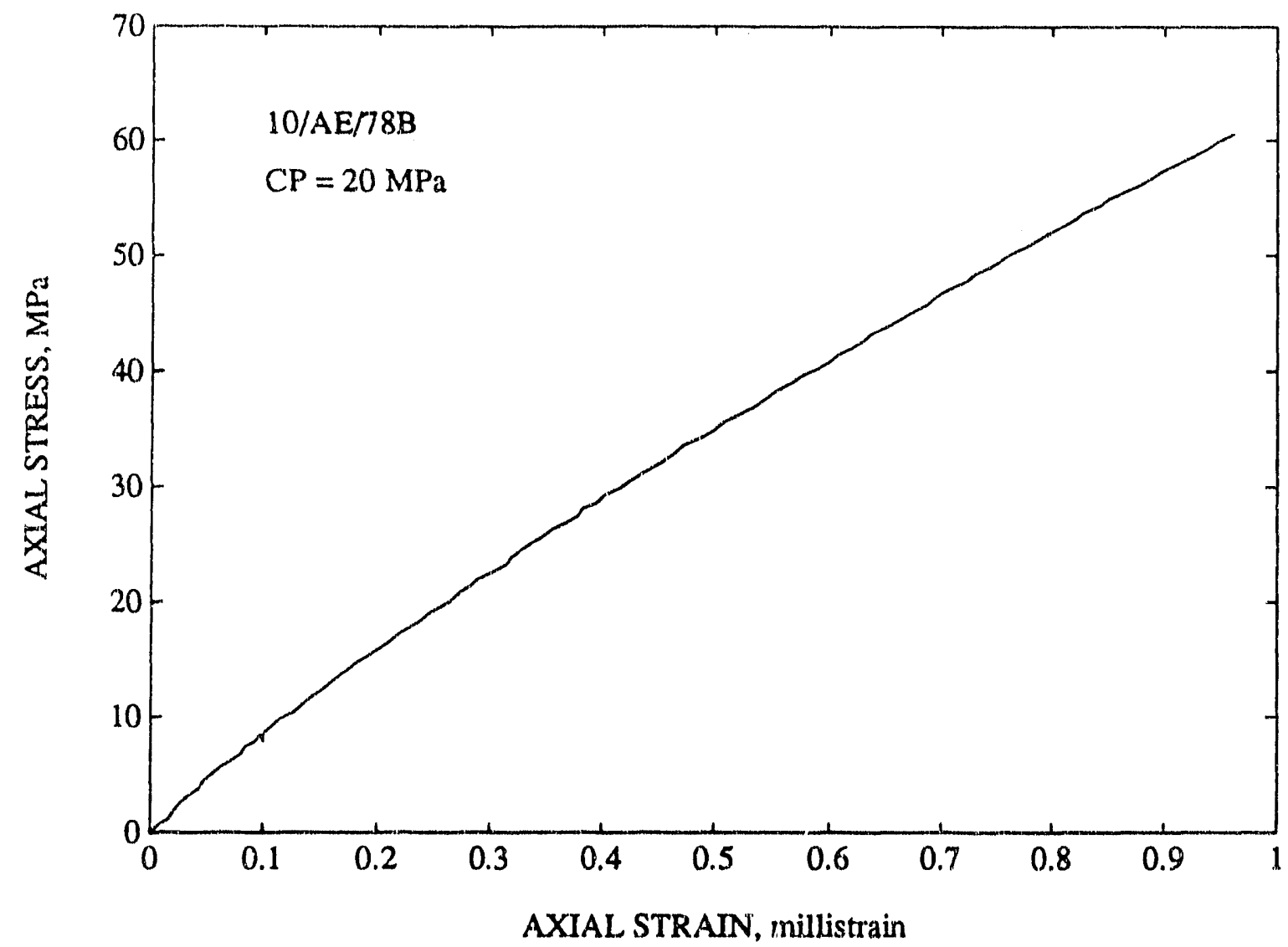

Figure 5. Axial stress is plotted as a function of axial strain for a compression experiment at a confining pressure of $20 \mathrm{MPa}$. The compression direction was normal to the layering. 


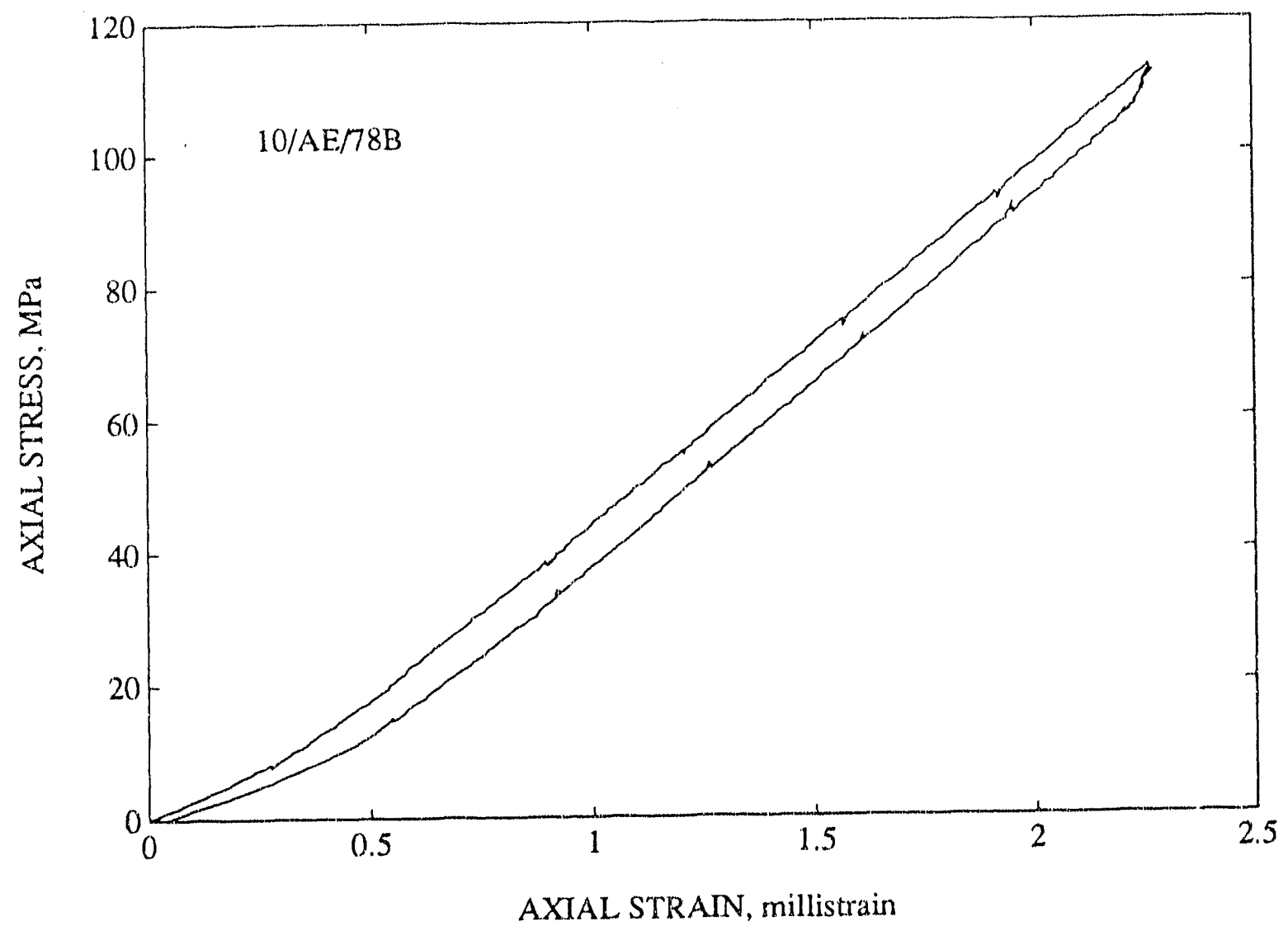

Figure 6. Axial stress is plotted as a function of axial strain for a uniaxial strain experiment. The compression direction was normal to the layering. 


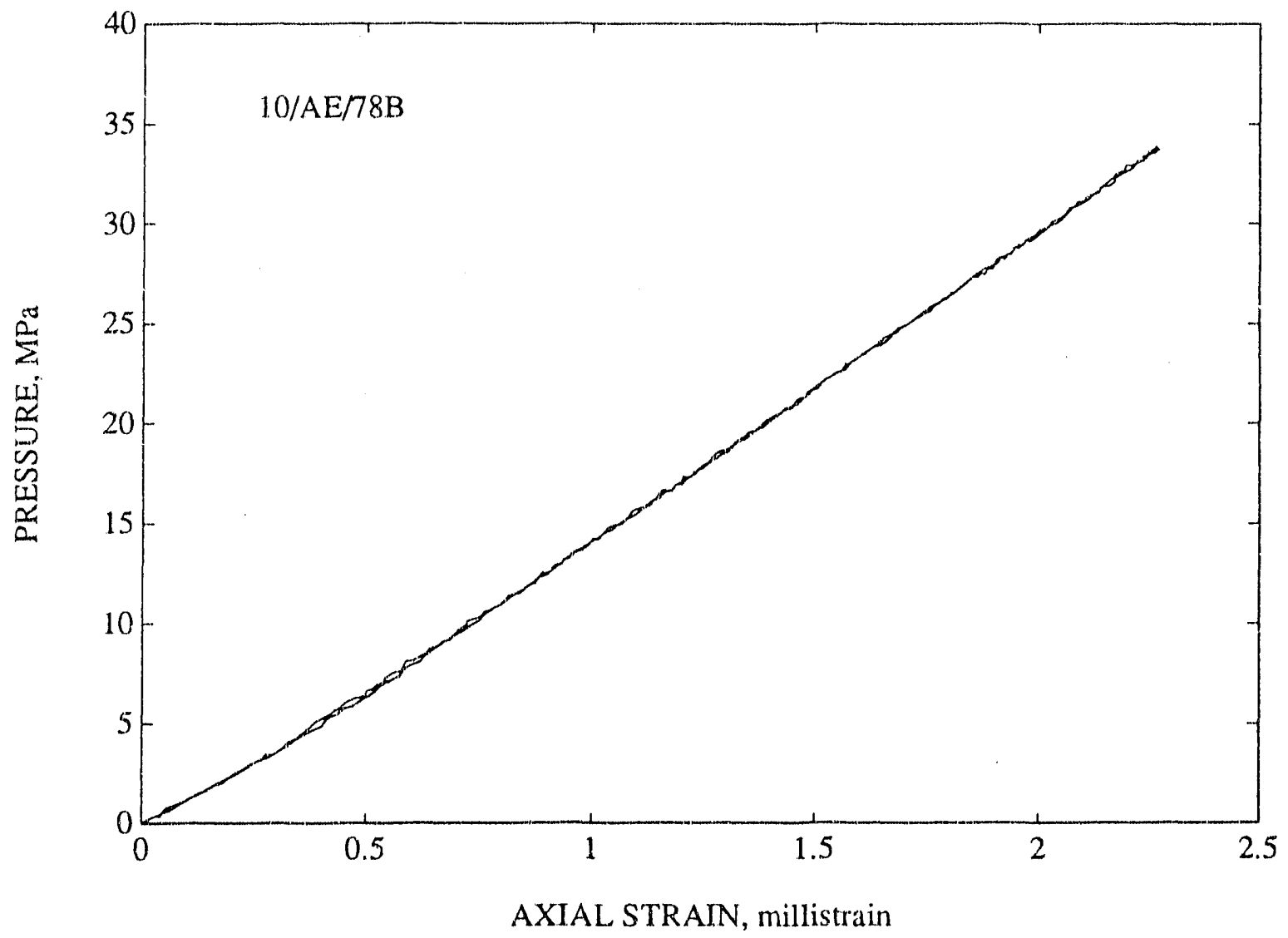

Figure 7. Confining pressure is plotted as a function of axial strain for a uniaxial strain experiment. 


\section{Appendix}

Information from the Reference Information Base

Used in this Report

This report contains no information from the RIB.

Candidate Information for the

Reference Information Base

This report contains no candidate information for the RIB.

Candidate Information for the

Site \& Engineering Properties Data Base

This report contains no candidate information for the SEPDB. 
1 J. W. Bartlett, Director (RW-1) Office of Civilian Radioactive

Waste Management

U.S. Department of Energy

1000 Independence Avenue, S.W.

Washington, DC 20585

1 F. G. Peters, Deputy Director (RW-2)

Office of Civilian Radioactive

Waste Management

U.S. Department of Energy

1000 Independence Avenue, S.W.

Washington, DC 20585

1 T. H. Isaacs (RW-4)

Office of Strategic Planning and International Prugrams Office of Civilian Radioactive Waste Management

U.S. Department of Energy

1000 Independence Avenue, S.W.

Washington, DC 20585

1 J. D. Saltzman (RW-5)

Office of External Relations

Office of Civilian Radioactive

Waste Management

U.S. Department of Energy

1000 Independence Avenue, S.W.

Washington, DC 20585

1 Samuel Rousso (RW-10)

Office of Program and Resources Management

Office of Civilian Radioactive Waste Management

U.S. Department of Energy

1000 Independence Avenue, S.W:

Washington, DC 20585

1 J. C. Bresee (RW-10)

Office of Civilian Radioactive Waste Management

U.S. Department of Energy

1000 Independenc? Avenue, S.W.

Washington, DC 20585

1 C. P. Gertz (RW-20)

Office of Geologic Disposal

Office of Civilian Radioactive

Waste Management

U.S. Department of Energy

1000 Independence Avenue, S,W.

Washington, DC 20585
1 S. J. Brocoum (RW-22)

Analysis and Verffication Division

Office of Civilian Radioactive

Waste Management

U.S. Department of Energy

1000 Independence Avenue, S.W.

Washington, DC 20585

$1 \mathrm{~J}$, Roberts, Acting Assoc. Dir. (RW-30)

Office of Systems and Compliance

Office of Civilian Radioactive Waste Management

U.S. Department of Energy

1000 Independence Avenue, S.W.

Washington, DC 20585

1 J. Roberts (RW-33)

Director, Regulatory Compliance Division

Office of Civilian Radioactive Waste Management

U.S. Department of Energy

1000 Independence Avenue, S.W.

Washington, DC 20585

1. G. J. Parker (RW-332)

Office of Civilian Radioactive

Waste Management

U.S. Department of Energy

1000 Independence Avenue, S.W.

Washington, DC 20585

1 R. A. Milner (RW-40)

Office of Storage and Transportation

Office of Civilian Radioactive

Waste Management

U.S. Department of Energy

1000 Independence Avenue, S.W.

Washington, DC 20585

1 S. Rousso, Acting Assoc. Director ( $R W-50)$

Office of Contract Business

Management

Office of Civilian Radioactive Waste Management.

U.S. Department of Energy

1000 Independence Avenue, S.W.

Washington, DC 20585 
1 Trudy Wood (RW-52)

Director, M\&O Management Division

Office of Civilian Radioactive

Waste Management

U.S. Department of Energy

1000 Independence Avenue, S.W.

Washington, DC 20585

1 D. U. Deere, Chairman

Nuclear Waste Technical Review Board

1100 Wilson B1vd. \#910

Arlington, VA 22209-22.97

1 Dr. Clarence R. Allen

Nuclear Waste Technical Review Board 1000 E. California Blvd.

Pasadena, CA 91106

1 Dr. John E. Cantlon

Nuclear Waste Technical Review Board 1795 Bramble Dr.

East Lansing, MI 48823

1 Dr. Melvin W. Carter

Nuclear Waste Technical Review Board 4621 E11isbury Dr., N.E.

Atlanta, GA 30332

1 Dr. Donald Langmuir

Nuclear Waste Technical Review Board 109 So. Lookout Mountain Cr.

Golden, CO 80401

1 Dr. D. Warner North

Nuclear Waste Technical Review Board Decision Focus, Inc.

4984 El Camino Real

Los Altos, CA 94062

1 Dr. Dennis L. Price

Nuclear Wast Technical Review Board

1011 Evergreen Way

Blacksburg, VA 24060

1 Dr. Ellis D. Verink

Nuclear Waste Technical Review Board 4401 N.W. 18th Place

Gainesville, FL 32605

5 C. P. Gertz, Project Manager

Yucca Mountain Site Characterization

Project office

U.S. Department of Energy

P.O. Box 98608--MS 523

Las Vegas, NV 89193-8608
1 C. L. West, Director

Office of External Affairs

DOE Field Office, Nevada

U.S. Department of Energy

P.O. Box 98518

Las Vegas, NV 89193-8518

12 Technical Information officer DOE Nevada Field office

U.S. Department of Energy

P.O. Box 98518

Las Vegas, NV 89193-8518

1 P. K. Fitzsinmons, Technical

Advisor

Office of Assistant Manager for

Environmental. Safety and Health

DOE Field Office, Nevada

U.S. Department of Energy

P.O. Box 98518

Las Vegas, NV 89193-8518

1 D. R. Elle, Director

Environmental Protection Division

DOE Nevada Field Office

U.S. Department of Energy

P.O. Box 98518

Las Vegas, NV 891.93.851.8

1 Repository Licensing \& Quality Assurance

Project Directorate

Division of Waste Management

U.S. Nuclear Regulatory Commission

Washington, DC 20555

1 Senior Project Manager for Yucca Mountain

Repository Project Branch

Division of Waste Management

U.S. Nuclear Regulatory Commission

Washington, DC 20555

1 NRC Document Control Desk

Division of Waste Management

U.S. Nuclear Regulatory Commission

Washington, DC 20555

1 P. T. Prestholt

NRC Site Representative

301 E. Stewart Ave., Room 203

Las Vegas, NV 89101

1 E. P. Binnall

Field Systems Group Leader

Building 50B/4235

Lawrence Berkeley Laboratory

Berkeley, CA 94720 
1 Centex fox Nuclear Waste

Regulatory Analyses

6220 Culebra Road

Drawer 28510

San Antonio, TX 78284

3 W. L. Clarke

Technical Project Officer for YMP

Attn: YMP/LRC

Lawrence Livermore National

Laboratory

P.O. Box 55.14

Livermore, CA 94551

4 R. J. Herbst

Technical Project officer for YMP

N-5, Mail Stop J521

Los Alamos National Laboratory

P.O. Box 1663

Los Alamos, NM 87545

1 H. N. Kalia

Exploratory Shaft Test Manager

Los Alamos National Laboratory

Mail Stop 527

101 Convention Center Dr., Suite 820

Las Vegas, NV 89109

1 J. F. Divine

Assistant Director for

Engineering Geology

U.S. Geological Survey

106 National Center

12201 Sunrise Valley Dr.

Reston, VA 22092

6 L. R. Hayes

Technical Project officer

Yucca Mountajn Project Branch--MS 425

U.S. Geological Survey

P.O. Box 25046

Denver, CO 80225

1 V. R. Schneider

Asst. Chief Hydrologist--MS 414

Office of Program Coordination

\& Technical Support

U.S. Geological Survey

12201 Sunrise Valley Drive

Reston, VA 22092
1 J.S. Stuckless

Geological Division Coordinator MS 913

Yucca Mountain Project

U.S. Geological Survey

P.O. Box 25046

Denver, CO 80225

1 D. H. Appe1, Chief

Hydrologic Investigations Program MS 421

U.S. Geological Survey

P.O. Box 25046

Denver, CO 80225

1 E. J. Helley

Branch of Western Regional Geology MS 427

U.S. Geological Survey

345 Middlefield Road

Menlo Park, CA 94025

1 R. W. Craig, Chief

Nevada Operations office

U.S. Geological Survey

101 Convention Center Drive

Suite 860, MS 509

Las Vegas, NV 89109

1 D. Zesiger

U.S. Geological Survey

101 Convention Center Dr.

Suite 860 - MS 509

Las Vegas, NV 89109

1 R. V. Watkins, Chief

Project Planning and Management

U.S. Geological Survey

P. O. Box 25046

421 Federal Center

Denver, CO 80225

1 A. L. Flint

U.S. Geological Survey

MS 721

P.0. Box 327

Mercury, NV 89023

1 D. A. Beck

U.S. Geological Survey

1500 E. Tropicana, Suite 201

Las Vegas, NV 89119 
1 P. A. Glancy

U.S. Geological Survey

Federal Building, Room 224

Carson Clty, Ny 89701

1 Sherman S. C. Wu

Branch of Astrogeology

U.S. Geological Survey

2255 N. Gemint Dr.

Flagstaff, AZ 86001

1 J. H. Sass

Branch of Tectonophysics

U.S. Geological Survey

2255 N. Gemini Dr.

Flagstaff, AZ 86001

1 DeWayne A. Campbel1

Technical Project Officer for YMP

U.S. Bureau of Reclamation

Code D-3790

P.O. Box 25007

Denver, CO 80225

1 K. W. Causseaux

NHP Reports Chlef

U.S. Geological Survey

421 Federal Center

P.0. Box 25046

Denver, CO 80225

1 W. R. Keefer

U.S. Geological Survey

913 Federal Center

P.0. Box 25046

Denver, CO 80225

1 M. D. Voegele

Technical Project officer for YMP

Science Applications International Corp.

101 Convention Center Dr.

Suite 407

Las Vegas, NV 89109

2 L. D. Foust

Nevada Site Manager

TRW Environmental. Safety Systems

101 Convention Center Drive

Suite 540, MS 423

Las Vegas, NV 89109
1 C. E. Ezra

YMP Support Project Manager

EG\&G Energy Measurements, Inc.

MS V-02

P.0. Box 1912

Las Vegas, NV 89125

1 R. E. Jackson, Program Manager

Roy F. Weston, Inc.

955 L'Enfant Plaza, Southwest

Washington, DC 20024

1 Technical Information Center

Roy $F$. Weston, Inc.

955 L'Enfant Plaza, Southwest

Washington, DC 20024

1 D. Hedges, Vice President,

Quality Assurance

Roy $F$. Weston, Inc.

4425 Spring Mountain Road, Suite 300

Las Vegas, NV 89102

1 D. L. Fraser, General Manager

Reynolds Electrical \& Engineering Co.

Mail Stop 555

P.O. Box 98521

Las Vegas, NV 89193-8521

1 R. F. Pritchett

Technical Project officer for YMP

Reynolds Electrical \& Engineering Co. MS 408

P.0. Box 98521

Las Vegas, NV 89193-8521

1 B. W. Colston

President/General Manager

Las Vegas Branch

Raytheon Services Nevada

MS 416

P.O. Box 95487

Las Vegas, NV 89193-5487

1 R. L. Bullock

Technical Project officer for YMP

Raytheon Services Nevada

Suite P250, MS 403

101. Convention Center Dr.

Las Vegas, NV 89109

1 R. E. Lowder

Technical Project officer for YMP

MAC Technical Services

101 Convention Center Drive

Suite 11.00

Las Vegas, NV 89109 
1 Paul Eslinger, Manager

PASS Program

Pacific Northwest Laboratories

P.O. Box 999

Richland, WA 99352

1 A. T. Tamura

Science and Technology Division office of Scientific and Technical Information

U.S. Department of Energy

P. 0. Box 62

Oak Ridge, TN 37831

1 Carlos G. Be11, Jr.

Professor of Civil Engineering

Civil and Mechanical Engineering Department

University of Nevada, Las Vegas

4505 South Maryland Parkway

Las Vegas, NV 89154

1. C. F. Costa, Director

Nuclear Radiation Assessment Division

U.S. Environmental. Protection Agency

Environmental Monitoring Systems Laboratory

P.O. Box 93478

Las Vegas, NV 89193-3478

1 ONWI Library

Battelle Columbus Laboratory

Office of Nuclear Waste Isolation $505 \mathrm{King}$ Avenue

Columbus, $\mathrm{OH} 43201$

1 T. Hay, Executive Assistant

Office of the Governor

State of Nevada

Capitol. Complex

Carson City, NV

89710

3 R. R. Loux, Jr.

Executive Director

Nuclear Waste Project Office

State of Nevada

Evergreen Center, Suite 252

1802 North Carson Street

Carson City, NV 89710
1 C. H. Johnson

Technical Program Manager

Nuclear. Waste Project Office

State of Nevada

Evergreen Center, Suite 252

1802 North Carson Street.

Carson City, NV 89710

1 John Fordham

Water Resources Center

Desert Research Institute

P.O. Box 60220

Reno, NV 89506

1 Dr. Martin Mifflin

Water Resources Center

Desert Research Institute

2505 Chandler Avenue, Suite 1

Las Vegas, NV 89120

1. Eric Anderson

Mountain West Research-Southwest Inc.

2901 N. Central Ave. \#1000

Phoenix, AZ 85012-2730

1 Department of Comprehensive Planning Claxk County

225 Bridger Avenue, 7 th Floor

Las Vegas, NV 89155

1 Planning Department

Nye County

P.O. Box 153

Tonopah, NV 89049

1 Lincoln County Commission

Lincoln County

P.O. Box 90

Pioche, NV 89043

5 Judy Foremaster

City of Caliente

P.O. Box 158

Caliente, NV 89008

1 Economic Development Department City of Las Vegas

400 East Stewart Avenue

Las Vegas, NV 89101

1 Community Planning \& Development City of North Las Vegas

P.O. Box 4086

North Las Vegas, NV 89030 
1 Director of Community Planning City of Boulder City

P.O. Box 367

Boulder City, NV 89005

1 Commission of the European Communities

200 Rue de la Loi

B-1049 Brussels

BELGIUM

2 M. J. Dorsey, Librarian

YMP Research and Study Center

Reynolds Electrical \& Engineering Co., Inc.

MS 407

P.0. Box 98521

Las Vegas, NV 89193-8521

1 Amy Anderson

Argonne National Laboratory

Building 362

9700 So. Cass Ave.

Argonne, IL 60439

1 Steve Bradhurst

P. 0. Box 1510

Reno, NV 89505

1 Vernon Poe

P.0. Box 1026

Hawthorne, NV 89415

1 Jason Pitts

Lincoln County Courthouse

Pioche, NV 89043

1 Michael L. Baughman

35 Clark Road

Fiskdale, MA 01518

1 Glenn Van Roekel

Director of Community Development

P.O. Box 158

Caliente, NV 89008

1 Ray Williams, Jr.

P.0. Box 10

Austin, NV 89310

1 Leonard J. Fiorenzi

P.0. Box 257

Eureka, NV 89316
1 Brad Mettam

P.O. Box 539

Goldfield, NV 89013

1 Bjorn Selinder

190 W. First St.

Fallon, NV 89406

1 Charles Thistlethwaite, AICP

Associate Planner

Planning Department.

Drawer L.

Independence, CA 93526

10 R. J. Martin, III

New England Research, Inc.

76 01cott Drive

White River Junction, VT 05001

16300 D. E. Miller

16302 T. E. Blejwas

$16312 \quad$ F. W. Bingham

16313 L. S. Costin

26318 R. J. Macer for 100/1232.713/SAND91-0894/NQ

26318 F. Cheek-Martin for DRMS file 51/L02-04/06/87

16319 R. R. Richards

256115 R. H. Price

7141 S. A. Landenberger

8 7613-2 Document Processing

for DOE/OSTI

37151 G. C. Claycomb

16115 P. J. Hommert, Acting

206341 WMT Library

16410 D. A. Dahlgren

1 8523-2 Central Technical. Files 

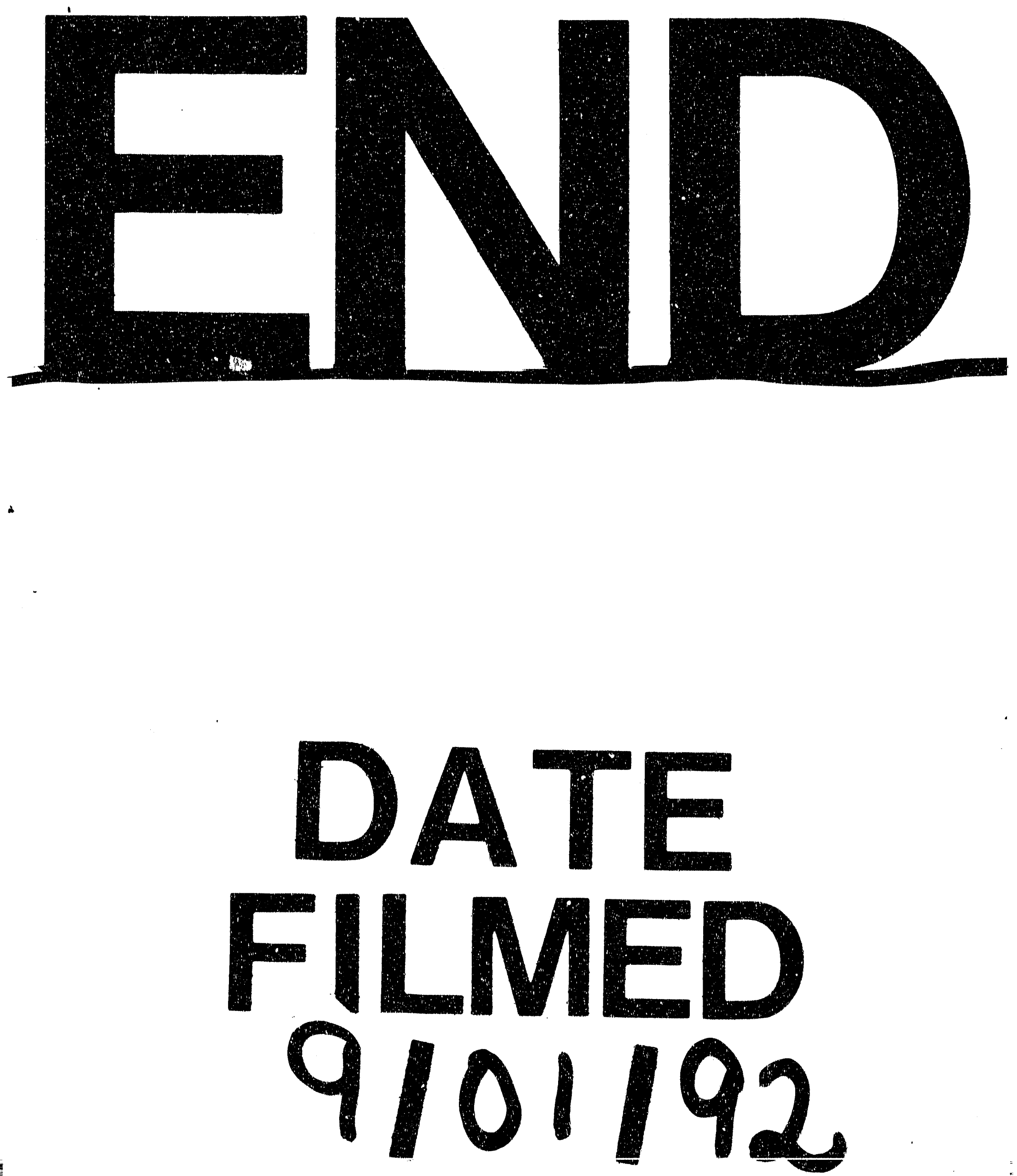

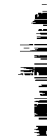




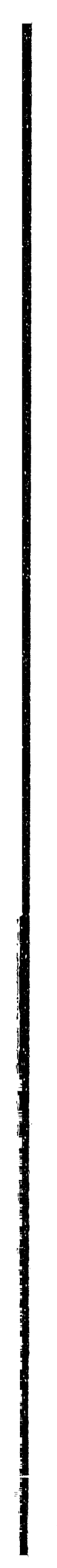

